\title{
SEDUCTIVE PLEASURES, ELUDING SUBJECTIVITIES: SOME THOUGHTS ON DANGDUT'S AMBIGUOUS IDENTITY
}

\author{
Bettina David
}

\section{Introduction}

The Indonesian popular music genre called dangdut, a unique hybrid mixture of mainly Western, Indian and Malay musical elements, has long been associated with the lower classes and cheap escapist, often highly sexualised, entertainment (Frederick 1982; Pioquinto 1995; Browne 2000; Wallach 2008; Weintraub 2010). ${ }^{1}$ In the 1990s, dangdut was increasingly appropriated by the elite, leading to media discourses of it as a 'very very Indonesian'2 music. There was even speculation about its potential for 'going international. ${ }^{3}$ Yet, in addition to this optimistic discourse, both in late New Order Indonesia and - even fiercer - in the post-Suharto era, there have been continuous debates about dangdut's 'appropriate' form, particularly with regard to the erotic dancing styles typical of the performance of the female singers. While Rhoma Irama, with his populist Islamic dangdut style, often called dangdut dakwah (Islamic proselyting dangdut), may during the New Order have been the established raja dangdut or 'king of dangdut', it is in fact the vulgar eroticism of many lower class kampung ${ }^{4}$-style dangdut shows that gives rise to most Indonesians' associations and fantasies about the genre. There seems to be no neutral position with regard to dangdut: Indonesians tend to either love it (usually the lower classes) or despise it (the middle classes and the elite) as something embarrassingly kampungan - that is, 'cheap' and 'low-class'.

\footnotetext{
1 This chapter is based on a paper that was written for the 2003 KITLV international workshop 'Southeast Asian Pop Music in a Comparative Perspective'; it was slightly updated and partly revised in early 2013. I am grateful to Bart Barendregt and Jan van der Putten for their helpful comments on earlier versions of this chapter. Its remaining shortcomings are of course wholly mine.

2 In the words of former State Ministry Moerdiono, cited in Simatupang (1996:58).

3 See, for example, the interview with senior female singer Camelia Malik (2000).

4 Kampung means village or a poor, semi-rural village-like area in a town or city. 
From a more Islamic perspective, particularly the low-class, erotic performances by female singers may even be considered to be haram (forbidden by Islam), and be campaigned against, as happened with the East Javanese singer-dancer Inul whose (in)famous 'drilling' (ngebor) buttocks gained international notoriety - one of the rare instances when contemporary Indonesian popular culture attracted brief global attention as some kind of exotic sensation. ${ }^{5}$

In this chapter, I offer some general thoughts about the socially mediated cultural aesthetics that may be at work in making dangdut such a pleasure to its fans, and at the same time such a contested subject in the official public sphere of both late New Order Indonesia and the first decade after its demise in 1998. I suggest that some of the most distinctive pleasures dangdut offers might be related to multiple contradictions inherent in its social constitution. Dangdut's prominent inclusive character, not only as a hybrid musical genre, but also socially as a strong statuslevelling force, as well as the ambiguity and multiple meanings of its lyrics, performances and consumption practices have been explored before (Wallach 2008; Weintraub 2010; see also Wallach in this volume). Here I take a closer look at the euphoria-inducing psychodynamics of dangdut that, as I suggest, constitute a subjectivity 'tainted' by a strong 'tolerance of ambiguity' (Bauer 2011). In so doing I hope to offer some additional ideas about dangdut's social positioning as an ideologically contested object of middle class and elite anxieties.

In the first part, the main focus is on the song lyrics and their relationship to common consumption practices. I suggest that it might be precisely the interplay of often contradictory significations at the levels of discursive symbolism (the lyrics) on the one hand, and presentational symbolism $^{6}$ (the music, rhythm and dance, that is, the non-verbal dimensions of the performance) on the other hand, that is crucial to our understanding of some aspects of its socio-cultural meaning. The emphasis here is especially on the sad lyrics, as I try to understand why they can be danced to with the dream-like pleasure typical of dangdut dancing (joget or goyang). I believe that the pleasures (or 'dangers') of dangdut performances derive precisely from these contrasting levels of signification enacted in performance by the typically female singer and the predominantly male

\footnotetext{
5 For detailed accounts and analyses of the 'Inul controversy', see Heryanto (2008) and Weintraub (2008).

6 I borrow the terms 'discursive symbolism' and 'presentational symbolism' from Langer's (1957) philosophy of symbolic forms.
} 
dancing audience: the interplay of the rational, verbal dimension of the song lyrics and the corporeal-rhythmic dimension of non-verbal sensuality.

In the concluding part, I propose that dangdut's dangerously seductive powers vis-à-vis both New Order developmental discourses as well as current Islamic discourses might be related to highly ambiguous feelings about a surrender to the power of an inclusive femininity. This may account for dangdut's characteristic, highly populist and status-leveling force, constituting a communitas of shared Indonesian-ness that nevertheless fails to integrate the middle and upper classes (Wallach 2008). In contrast to Islam, which also offers a shared communitas, dangdut's contested idiom of subjectivity has so far not been able to constitute an idealized vision of a modern Indonesian subject that is able to actively shape the postcolonial nation-state and whose identity is recognized globally.

But first, in order to highlight some distinctive features that characterize dangdut and that will be elaborated on in the analysis that follows, I will briefly compare dangdut with two similar musical genres, Turkish arabesk and Algeria's raï.

\section{Dangdut in Cross-Cultural Perspective}

Dangdut is a local part of the global mass-mediated pop music industry. Musically influenced by popular Malay tunes and Hindi film songs, and later by Western pop and rock music, its development has been closely related to the emerging entertainment and electronic mass media industry in post-colonial Indonesia. ${ }^{7}$ In many ways dangdut's social and musical background is comparable to two similar non-Western hybrid popular music styles: Algeria's raï and Turkey's arabesk. Both of these are hybrid in musical terms, that is, they incorporate influences of Western pop music as well as various indigenous musical traditions and recently, like dang$d u t$, increasingly influences from other Non-Western popular musical styles such as Latin American music. They are associated mostly with the lower classes and the urban poor, exist alongside local pop music genres which are 'Western' in musical idiom (like pop Indonesia), and are part of the urban lifestyle of the educated middle and upper classes. Like dangdut, both raï and arabesk are pop music genres of Muslim societies.

7 For an account of the historical development of dangdut and the various musical influences incorporated into this genre, see Frederick (1982) and Weintraub (2010). David (2008) refers to the influence of Bollywood film songs on dangdut. 
My comparison will focus on two aspects in raï and arabesk: the content of the song lyrics and consumption practices.

\section{Song Lyrics}

In terms of lyrics, both raï and arabesk convey a strongly 'male' point of view. They can be characterized as 'male' pop music styles, as most of the singers and stars are male, and the lyrics they sing speak from a distinctly 'male' perspective. Raï lyrics are mostly about 'the male spheres of pleasure, alcohol and women' (Schade-Poulsen 1995:91), and often also about 'available' women in bars and relationships with them in the 'asocial' woods, i.e. a terrain symbolically opposed to the ordered world of the village. Schade-Poulsen (1995:95) observes that

[1]istening to raï with the family poses major problems. The simple evocation of the woods, drinking, women that drink, and even of raï itself, creates embarrassment in many families.

In contrast to this, the possible embarrassment caused by speaking about or listening to dangdut is strongly related to class issues. In the urban lower classes, it may be enjoyed in domestic contexts by the whole family without any embarrassment at all, grannies spontaneously dancing along to the music with their grandchildren (see Wallach in this volume). At the height of the Inul craze, it was not uncommon to see veiled women cheering enthusiastically at toddler girls trying to 'drill' their buttocks like Inul.

Arabesk is also associated with these 'male spheres of pleasure' with alcohol being one of the central topoi of the lyrics. Stokes (1992:148) writes:

In arabesk lyrics, the emphasis is upon alcohol as a refuge and consolation, its consumption an act of simultaneous self-gratification and selfdestruction.

The themes of sexuality and alcohol are part of the wider discourse of love in these lyrics. Yet, it is interesting to note that it is the dark side of love that is explored most deeply in raï and arabesk lyrics. In raï, the predominant notion of love is 'a relationship which basically gives great pain to the man involved [...]' (Schade-Poulsen 1995:98). Arabesk explores themes of grief, separation, loneliness, and alienation (Stokes 1992:128). Stokes (1992:13) speaks of an 'impotent pathos' in arabesk lyrics:

[the] dominant images associated with the genre, in films, lyrics, and the remarkable personalities of the singers, are [...] images of a peculiarly emasculated manhood $[\ldots]$. 
A similar 'impotent pathos' can indeed be found in many dangdut songs sung by male singers, and many songs are about lost or betrayed love, leaving the male lyrical persona alone and helpless in his sadness and fatalist agony. ${ }^{8}$ Songs like these are often accompanied by rather pathetic gestures and tragic facial expressions in video clips. Yet surprisingly, there seem to be no songs in which the male singer explicitly links his grief and alienation with the pleasures of alcohol as a refuge, for example by praising alcohol's faithfulness in contrast to the loved one who has gone, or in a fatalist acceptance of both the pleasures and the self-destruction it brings in even further isolating the man from the social world. ${ }^{9}$ Seen from an intimate male perspective, alcohol is definitely not a common subject of dangdut lyrics.

This is interesting, not only because alcohol is quite commonly consumed at live outdoor dangdut concerts, but also because alcoholism as a stereotypical male shortcoming features quite prominently in dangdut songs sung by female singers. One of the best-known songs here is perhaps Cucu Cahyati's Mabuk dan judi (Drunkenness and gambling) from the early 1990s. In this song, the singer complains in an up-front way about her lover/husband-to-be being drunk again with his friends and gambling with them, and she tells him she will leave him if he doesn't change and becomes a dependable man. The complaint about a man who lets himself go and avoids taking responsibility for his actions is a common topos in the songs of female singers. There is quite a list of stereotypical bad male characteristics like alcoholism and gambling, laziness, irresponsibility, daydreaming, endless womanising, and even physical abuse/domestic violence, and the female voice in these lyrics can be at times quite accusing and aggressive. ${ }^{10}$ In the male songs, however, the complaints about women remain relatively vague and are even interchangeable with those female songs in which the singer complains about money and status being more important to her (ex-)lover than love and faithfulness, not to mention the abundant laments over betrayal and unfaithfulness that are common in both male and female songs.

8 For example, in Meggy Z.'s Merana (Ailing): 'I tried to make my heart forget the first love [...], my wounded heart now hurts even more, its mourning will never ease, it leaves me in this ailing state now, without any power to chase away the sadness and misery.'

9 There is, to be sure, a song by Rhoma Irama about the dangers of alcohol and drugs, Mirasantika, but its lyrics convey nothing of the very intimate, private perspective of typical arabesk songs, and rather speak from a moralist meta-position.

10 For example in songs during the 1990s, on womanizing husbands Cinta tak seperti gaun (Love is not like a gown), by Yulia Citra; on the abusive husband/lover Kejam (Cruel) by Elvy Sukaesih. 
However, in some female songs like Itje Trisnawati's hit song of the early 1990s, Duh engkang (Oh my husband), the woman even reminds the man of his social duties, of God, and what it means to be an adult man and a responsible member of society. Thus, in the context of the song narrative, the female voice at times speaks to the man from the moral position of a 'civilizing' authority, representing the norms of the social world and invoking them against the threat posed by male self-indulgent irresponsibility.

Moreover, in dangdut's gender discourse the male invoked by some song lyrics not only tends to be unfaithful and irresponsible, there is interestingly also the topos of the missing male, like in such 199os songs as Iis Dahlia's Pengantin palsu (False bridegroom), in which the bridegroom doesn't show up at his own wedding, or disappears on the wedding night as he does in Cucu Cahyati's Seprei pengantin (Wedding bed sheet), or is taken away by the police at his wedding because he is, as it turns out, a wanted criminal (Aib [Disgrace] by Ikke Nurjanah). Thus, the male either fails to live up to social and intimate expectations, or is at times completely missing.

It is intriguing to note, therefore, that in dangdut lyrics far more stereotyped criticism seems to be voiced against men than against women. This rather strong emphasis on a female point of view, which is reinforced by the fact that far more songs are sung by females than by males, is interesting not just in cross-cultural comparison. In contrast to the hegemonic official discourse of New Order Indonesia that tended to downplay or silence female voices (Sen 1993, 1994; Sunindyo 1993), the discourse of many dangdut lyrics is thus clearly informed by popular, 'unofficial' gender constructions widely known in the Malay archipelago. These constructions have been termed 'practical' by Peletz, as they are oriented on the practical realities of everyday life and on 'getting things done' (Peletz 1996:4; see also Brenner 1998). In these 'practical' gender constructions, men are held to be less responsible and less trustworthy than women, both with regard to managing house-hold resources, and in terms of honouring basic social obligations associated with marriage and kinship as a whole' (Peletz 1996:4). This alleged male tendency towards familial and social irresponsibility is indeed a typical subject of female dangdut lamentations. In dangdut song narratives, the woman quite often 'speaks', and far from being silenced, she complains about her suffering, about male double standards, or even about male absence, often using grotesque, highly exaggerated images. 


\section{Consumption Practices}

Now what do people do with these lyrics? The obvious contradiction between often sad and fatalistic lyrics, or even lyrics that point toward the male as being responsible for the suffering of the female lyrical persona, and the blissful dancing to these songs by the usually male audience at live shows has been noted by Wallach (2008) and Weintraub (2010). However, in order to see dangdut's distinctive characteristics regarding consumption more clearly, let us first take another short comparative look at common consumption practices of arabesk and raï.

According to common opinion, in both arabesk and raï the lyrics are central to the pleasure one gains from listening to these styles. Raï fans usually emphasize: 'When I hear the singer, it is as if I hear my own story' (cited in Schade-Poulsen 1995:88). Similarly for arabesk: 'When people talk about arabesk they do so in terms of the lyrics of the songs [...]' (Stokes 1992:133). The lyrics are explicitly referred to in intimate, private discourses of love and emotions. As Stokes (1992:129) notes: 'Arabesk is used [...] as a mode of self-representation, enabling people to talk about themselves to other people.' People consciously identify with the lyrics and cite them to express their inner selves in intimate moments.

This cannot be said to the same extent of dangdut as there seems to be a rather ambivalent response to the lyrics: media discourses as well as dangdut fans from the lower classes argue that the sad, fatalistic lyrics represent the feelings and experiences of the poor, their daily hardships and powerlessness in the face of highly unjust social conditions. For example, the women's magazine Sarinah told its readers in 1992: 'Dangdut $[\ldots]$ is loved by the lower classes because it touches as well as represents the people who feel that it is their fate expressed in the sad lyrics.'11 (Sarinah 1992:3). However, in contrast to common social usage of arabesk and raï, rather than providing an idiom of serious, intimate discourses about love and emotions - that is, something not to just laugh about, but rather to be taken seriously in all its depth -, dangdut seems to be used more as a collective idiom to alleviate stress by playfully teasing each other or making rather (self-)ironic or mocking references to popular dangdut songs. This social usage seems to be linked to the strong cultural expectation of keeping informal social intercourse generally cheerful and gay. Dangdut is not so much used as a language to express one's deep

11 All translations from Indonesian are by the author, unless indicated otherwise. 
personal feelings, but rather as a mode that enables people to enjoy being together in a spirit of shared sociability, while still acknowledging life's darker sides through the song lyrics (cf. Wallach 2008:9). Moreover, the highly exaggerated pathos of many lyrics encourages an ironic stance that fosters collective identification and feelings of belonging in an atmosphere of shared playfulness.

Dangdut's main pleasure is usually said to lie in its irresistible pulsating rhythm, making people automatically goyang (swing their hips) and joget (dance), as Sarinah is quick to tell its readers: 'The lulling melody, at times pulsating and swaying, entices people to join in the dancing, inviting them to forget their problems for a moment' (Sarinah 1992:3). This corporeal dimension of letting oneself be seduced by the alluring rhythm is far more pronounced in Indonesian discourses about dangdut than in comparable Muslim genres like arabesk and rä̈: It seems impossible to speak about dangdut without at the same time referring to the pleasures (or dangers) of goyang. Furthermore, like Sarinah, both media discourse and fans usually argue that dancing to dangdut songs helps people to briefly forget their problems (see, for example, Tony 1996). This is indeed interesting, since at the same time the song lyrics' often sad and fatalistic narratives are said to 'represent' the harsh daily realities of the poor. We may ask, therefore, sharpening the paradox: How are we to understand the fact that the male audience experiences deep pleasure in dancing to songs whose lyrics are quite often about stereotypical male shortcomings? Since the lyrical discourse is almost always embedded in a fictional relationship between an 'I' (the singer) and a 'you', many songs are indeed accusations - sometimes fierce and aggressive, sometimes more lamenting and fatalistic - that are addressed to the 'you' - that is, in the context of the performance, somebody/anybody in the male audience. So what is the pleasure in dancing to an erotically hip-swinging woman who sings lyrics like 'you betrayed my pure love' or 'you promised me paradise, but gave me hell'?

When asked about this, people tend to answer rather stereotypically that the lyrics are not really listened to; it is rather the seductive rhythm that brings the pleasure of dancing to it. But what is it that is articulated first within this cultural idiom, to only then allegedly be 'not listened to'? After all, if the lyrics were in fact 'not important', they could just as well be

12 To give just two examples: 'you betrayed this pure love, [...] I can't believe that you dared to defile love, to betray love' (Tenda biru/'Blue tent', sung by Minawati Dewi); 'paradise you promised, hell you gave' (Janji/ 'Promise', sung by Rita Soegiarto). 
very different. But they are not and they usually do not articulate beautiful escapist dreams. Quite the opposite, in fact. Yet, considering the immense pleasure that fans usually get from dangdut, both at informal roadside performances or at large outdoor concerts, it nevertheless seems to offer some very powerful and blissful dreams.

I suggest that one of dangdut's most seductive pleasures is related to the complex and ambiguous interplay between the level of symbolic signification, i.e., the song lyrics, and the corporeal-rhythmic level of nonverbal sensuality. In what follows I will first explore these dimensions of signification within the theoretical framework proposed by Julia Kristeva, which distinguishes between symbolic and semiotic dimensions of the signifying process and then conclude with some thoughts on the particular subjectivity that is constituted by dangdut.

\section{Semiotic Pleasures}

In her theoretical approach, drawing, among others on Lacanian psychoanalysis, Kristeva (1984) is concerned with bringing the speaking body back into philosophy and linguistics. She distinguishes between two heterogeneous elements in signification: the semiotic and the symbolic. The semiotic elements within the signifying process are the drives as they discharge within language. They are mainly associated with rhythm, tone, sound and gesture. This non-signifying 'material' of language is part of the child's first sensual experiences in its pre-oedipal relationship with the maternal body. The symbolic, on the other hand, is the signifying part of language, that is, the rules of syntax and grammar that enable language to become a means for taking a position or making a judgment. The symbolic also, through language and the positionality of subject and object implied by it, constitutes the symbolic order regulating social life that is associated with the paternal consciousness. However, the feminine and male dimensions here are not to be conflated with the gender identities of women and men, as both the semiotic and the symbolic are part of the psychic realities of both women and men and in fact necessary conditions for any constitution of the subject and society.

While music is a nonverbal signifying system relying almost exclusively on the semiotic, poetic language is the mode of discourse that allows the semiotic to 'irrupt' within the symbolic, as its attention to sounds and rhythms in language points to the semiotic element in signification. In challenging the static symbolic positions through its negativity vis-à-vis 
all subject positions, it represents an endless dynamic force of change and process.

Indonesian interpretations of dangdut often bear a great resemblance to Kristeva's notion of the semiotic in contrast with the static symbolic order. For example, Susanto states that:

the vulgarity of dangdut that is human in its utmost corporeality (spontaneous and fragile) lies opposite all those matters that have always been offered as interpretations (such as tradition, religion, moral, philosophy, art, and so on) (Susanto 1992:220).

It is precisely this corporeal 'directness' of dangdut, its spontaneous liveliness that works against static positioned meanings of the symbolic order that may account for the pleasure it makes possible. It challenges the symbolic order as it reveals the fragility of its structure and transcends its restrictions. Kristeva (1984:79f) emphasizes the jouissance that is associated with the semiotic breaking into the symbolic.

Regarding Kristeva's notions of the semiotic and the symbolic, we may understand the pleasure dangdut offers its audience as being related to precisely this semiotic dimension. This would indeed be congruent with what fans say about their love of dangdut when they tell us that, in contrast to the rhythm, the lyrics usually 'don't really matter'. Hence it is not so much the symbolic positing of an enunciation in the lyrics but rather the sensual interplay of the (usually) female voice, melody, and rhythm vis-à-vis the thetic position of the lyrics that is experienced as pleasurable, especially in identifying with it through dancing.

This is not to say that the lyrics are not important in this interplay of the semiotic and the symbolic. Quite the opposite: as the lyrics represent the symbolic level, they point toward the 'reality' of loss, alienation and separation - whose acknowledgment, from a Lacanian-influenced perspective, is a psychic precondition for entering the symbolic order that is based on the loss of pre-Oedipal maternal omnipotence. As the lyrics are about loss, they guard the symbolic order, offering people a chance to acknowledge these intimate feelings while at the same time indulging in the semiotic pleasure of identifying kinetically with the rhythm.

One of the many pleasures dangdut offers, especially for male fans, is of course the erotic spectacle that is so typical of kampung performances. Pioquinto (1995) and Browne (2000) have explored these voyeuristic pleasures. Numerous local female singers are indeed (in)famous for their daring individual styles of sexually suggestive goyang and attract huge crowds. Especially fans in the first rows beneath the stage, commanding 
the best view, clearly voyeuristically enjoy the titillating erotic spectacle. Fans also hold up their mobile phones, recording the gyrating hips of the female singer while obviously trying to catch a glimpse of her crotch.

But dangdut is about more than just cheap erotic entertainment for the poor masses. In fact, as noted before, dangdut's main pleasure seems to be about goyang, i.e., dancing. Dancing to dangdut is usually characterized as entering into a self-absorbed, dreamlike state of consciousness, in which the dancer's eyes are often closed - in spite of the 'hot' erotic show on the stage. This dance style is actually so characteristic that it easily lends itself to funny, exaggerated parodistical performances on TV comedy shows and for informal fun with friends. These mock the stereotypical lower class dangdut fan who is so easily possessed by dangdut's rhythm that within seconds he forgets everything around him.

Explaining dangdut's seductive appeal in mainly voyeuristic terms thus cannot explain the pleasure experienced by those dancers who seem to be wrapped in their own inner worlds, letting their bodies be moved by the rhythm. Moreover, the voyeuristic framework suggests a splitting of subject and object, the erotic woman on stage being reduced to an object for male sexual fantasies. In contrast, I suggest that what the performance offers - besides the obvious voyeuristic element - is rather a pleasurable identification with the female singer via the strong rhythmic-corporeal dimension of the performance.

While in many songs the female lyrical persona of the symbolic level is a passive, suffering and powerless $a k u$, on the semiotic level of rhythmiccorporeal sensuality this $a k u$ is capable of exerting an immensely seductive power on the male audience. ${ }^{13}$ This may account for the feeling of empowerment that the female singers enjoy on stage, triumphantly exerting their erotic power on the audience (cf. Pioquinto 1995; Browne 2000; Bader 2011). Heryanto (2008:22-3), for instance, notes Inul's impressive command of authority of the situation in her early performances in East Java. It is indeed remarkable how female singers performing on kampung stages usually address the audience in strong, powerful, even aggressive

13 Dolar (2002:15) points toward the relationship between representations of female powerlessness and, simultaneously, the musical evoking of irresistible female power in Western opera. He also speaks of 'Diva, the goddess of the opera whose status depends on being in total despair, the goddess deprived of all power and hence the most powerful' (2002:15). The figure of the seductive and eroticised female singer-dancer is part of many cultures in the Malay Archipelago. See for example Sutton (1984) on the Javanese pesindhen, Spiller (2010) on Sundanese ronggeng, and Van der Putten (in this volume) on Malay ronggeng. 
voices, being anything but the demure, submissive and delicate ideal of femininity propagated by New Order ideology and similar gender ideologies advanced by conservative Islam. It is this corporeal, highly seductive power that dancers are identified with, a blissful reunion of the dancing bodies with the semiotic and erotically charged maternal body the female singer offers the audience.

\section{Dangdut's 'Noise', New Order's 'Voice': Who is Speaking?}

In order to contextualise dangdut's seductive yet at the same time dangerous appeal within the Indonesian socio-political landscape of the last three decades, let us take another look at the song lyrics and their language. Dangdut's Indonesian was the very antipode of the elaborated Indonesian of Suharto's New Order official culture. The similarity between formal New Order Indonesian and krama, the formal, refined, and highly ritualised speech register of the Javanese language, has been noted before (Anderson 1990; Matheson-Hooker 1995; see also Keane 2003). Regarding Suharto's speeches, Matheson-Hooker (1995) notes: 'The language and the style of the speeches is unemotional' (1995:280). There are 'no expressions of intimacy' (1995:278). It is all about stability and harmony (1995:287), change can only be conceived of as progress (1995:285). Suharto 'rarely uses the first person singular pronoun'. He spoke 'as one with full authority, who has the key to the nation's well-being and who holds a legitimate and institutionalised position', the implied audience was never addressed directly (1995:278). This contrasts sharply with the Indonesian as articulated in dangdut lyrics: in dangdut, the language is highly emotional, a single $a k u$ (intimate ' $\mathrm{I}$ ') speaks about his/her most intimate feelings and emotions, addressing a 'you' in a strongly phatic way. In many dangdut songs nothing remains of stability and harmony but broken, shattered illusions of the past. The focus is mostly on the past, and instead of progress or development, the lyrics are quite often about loss and powerlessness. The lyrical persona speaks from a position of marginality and helplessness, not authority. Dangdut's female $a k u$ speaker is definitely not part of the male-centered developmentalist ideology that characterized New Order hegemonic subjectivities.

Dangdut's marginality within the dominant discourse of official New Order Indonesian has allowed its lyrics to speak about otherwise tabooed topics like domestic violence. Like ngoko, because it has no 'official' authority, it can say things that may not be articulated as directly in krama 
or official Indonesian. The debate about the pop Indonesia song Hatiyang luka (Wounded heart) in 1988 exemplified this splitting of different domains that determine what may be spoken of in which ways. ${ }^{14}$ Hati Yang Luka is a 'weeping' (cengeng) song about domestic violence, and as such it was condemned for its weeping, fatalist character. Yet, many dangdut songs are even more fatalistic and weepy, and domestic violence may be articulated without necessarily giving rise to a ban. It seemed not to be the lyrical content of the song per se, but rather the cultural form/ dimension in which it was articulated that created such a scandal. Put bluntly, something usually said and spoken of in ngoko was suddenly articulated in the clean, upper-class and krama-like pop Indonesia, whose lyrics are usually quite elusive and vague. And while dangdut is a strongly rhythmic music that is famous for its seductive power, pop Indonesia is mostly a music that can barely be danced to. It presents no 'anarchic' corporeal-erotic excesses to be feared, in this regard it is 'clean' and 'safe', like krama.

Shiraishi (1997) points towards similar patterns of Indonesian language use that evolved during the New Order that seem to be relevant for dang$d u t$ as well. For example, she describes the 'two voices' in Indonesian classrooms: 'the authorized voice and the noise' (1997:135). The 'noise' is similar to dangdut and ngoko, as those noise-voices that are disregarded by the official, 'legitimate' sphere tend not to be totally suppressed, and so there is no strict internalisation of only one 'authorized voice'. Rather, Shiraishi points toward segregation as a central structuring principle that appears to be similar to the distinction between ngoko and krama in Javanese. One may note that this psychosocial structuring is significantly more characterized by segregation into different domains than by strict suppression/repression demanding the internalisation of only the 'authorized voice' into a single identity. Different, even contradictory aspects and ways of being may be tolerated side by side. There are spheres for krama as for ngoko ways of being, feeling and speaking.

This differs greatly from historic developments in Western mentality that has emphasized suppression/repression of disturbing 'noises', and instead enhances the internalisation of social norms into a single 'identity' for all occasions. Other, differing voices have, over centuries of Western 'cultural crusades' (Baumann 1993), long been eliminated or assimilated to the one Truth, both on the individual psychic level as well

14 For a detailed discussion of the song and its 'fate' as well as its avatars in different Indonesian pop music styles and regional languages, see Yampolsky (1989). 
as in the world (cf. Todorov 1984; Baumann 1993). In contrast, as for example Wallach (2008:189) has pointed out, Indonesians usually tend to prefer the noisy presence of multiple voices, coexisting side by side, over any attempt at forcing them into one unitary synthesis that eradicates contradictions and differences. This shows what Bauer (2011), referring to pre-colonial Islam's valuing of multiple, even contradictory meanings and a diversity of interpretations, has termed a high 'tolerance of ambiguity': a strong preference for a psychic flexible 'both - and' stance over a rigid 'either - or' mindset. For dangdut in the 1980s Weintraub (2010:146) argues that ' $[\mathrm{d}]$ angdut opened up interpretive possibilities rather than neatly closing them off. Dangdut did not provide answers to problems. Rather, it pushed the limits of what was allowable in order to expose an excess of possibilities.' In this sense, it could well be argued that dangdut is Indonesia's idiom par excellence to articulate its deep rooted cultural emphasis of polyvocality, giving a voice to its high tolerance of ambiguity.

However, within hegemonic New Order discourse, dangdut's voice was only assigned the status of a kind of ngoko/'noise'. Its concomitant associations with childlikeness and immaturity, something rather to be ashamed of, are also suggested by the distinctly pedagogic way of speaking about dangdut in the media during the 1990s. This was the time of increasing political instrumentalization by the government of dangdut's massive populist appeal (Weintraub 2010). Over and over we hear about dangdut not yet being dewasa (that is, 'adult' or 'grown up'), and that dangdut has to be 'educated' in order to become an adult, respected art form that may represent Indonesia by going international. The following excerpt from an article about dangdut in the prestigious daily newspaper Kompas is illustrative:

Regarding its "maturity", dangdut now appears more mature as can be seen, for example, in the singers' appearance, which is no longer "vulgar". Goyang dangdut, once a basic skill expected from every singer, is not so important nowadays. [...] Miniskirts, sexy outfits and abundant accessories are also becoming more and more rare among dangdut singers, especially among the successful women who made their way to the recording studios. In turn, this maturity is making dangdut music increasingly acceptable to the middle and upper classes. [...] One day dangdut music and dangdut singers will obtain a respectable place in the international world. Dangdut music will become something the Indonesian people are proud of, and it will strengthen the unity of the nation. (Yurnaldi and Rakaryan 1997)

Perceived as not yet 'mature', that is still 'childlike', are all aspects that might be associated with some sort of 'excess', be it the style of dance (too 
erotic) or costumes (too sexy, too many accessories, etc.). Similarly the audiences at kampung shows are seen as uncontrolled masses, driven by their instinctual desires, in contrast to 'adult' krama-awareness of how to behave properly in a disciplined, self-controlled manner. In order to move up the social strata into the realm of official, 'legitimate' culture, dangdut thus has to pay a price, that is, it needs to be 'cleaned up' to become acceptable. ${ }^{15}$

This late New Order discourse about dangdut points toward an ideological emphasis regarding the need to conform to what is imagined as an 'international standard'. It is a perspective from without, from a supposed 'international standard' point of view, asking whether 'we are conforming to the standards of the Other/West?'. Parts of one's own inner being and cultural idioms that articulate the subject positions associated with it are experienced as failing to live up to standards set up by the outside world, that is, the hegemonic West. This elite discourse of local art forms as being something rather embarrassingly 'messy' that need a thorough cleaningup and formation in order to upgrade them so that they will conform to 'modern', i.e. Western standards has long links back to colonial discourses (see, for example, Sears 1996 for wayang kulit).

The subject position offered by dangdut is indeed in many ways the antipode to the national subject constituted within New Order ideology: Not belonging to the male associated spheres of active subjectivity offered by politics, economy, the military and gender ideologies of male patriarchal dominance constituting the modern nation-state, dangdut's subject is often a male that has failed to live up to the expectations of both his female lover and society at large. At the same time he indulges in the blissful pre-symbolic realm of semiotic pleasures and playfulness beyond the usual adult social restrictions, thus challenging the inevitable unambiguity regarding subject positions claimed by any ideological discourse. Either distancing oneself by assuming a playful, pleasurable ironic stance towards the lyrics, or surrendering to the marginalized feminine voice and the erotically charged corporeal dimension, in which one loses oneself in its emotionally exaggerated pathos and its sensual excesses, this subject forever eludes any normative subject interpellations. ${ }^{16}$

\footnotetext{
15 See Browne (2000) for an account of efforts to 'clean up' dangdut. Interestingly, these efforts to 'clean up' dangdut are similar to developments in Algeria where there have been attempts to establish a 'clean rai' (raï propre) (Schade-Poulsen 1995:95).

16 One may even argue that in the interplay of lyrics (symbolic level of language) and corporeal pleasures (semiotic level of rhythm, melodic articulation, dance) the male dancers are offered the chance to 'not listen' to the lyrics in identifying with the semiotic. The
} 


\section{Seductive Subjectivities: Some Concluding Thoughts}

As Wallach points out (Wallach 2008; see also Wallach in this volume), dangdut's powerful 'inclusiveness', erasing boundaries and defying clearcut categorisations in constituting a communal populist idea of shared 'Indonesianness', eventually fails as the urban educated middle class and elite class-consciously resist its seductive powers. They allow themselves to be 'possessed' by dangdut's mighty sensual pull for only brief moments of indulgence in its 'guilty pleasure' (Wallach 2008:213). Dangdut seems to remind the middle and upper classes of something that still lurks deep inside them, which they experience as something highly ambivalent and disturbing. These disavowed subjectivity aspects continue to speak from behind the carefully cultivated appearances of consumerist lifestyles, whispering through the rhythm's irresistibility that they are still part of the collective body of that huge other Indonesia of the lower classes with whom they share a common origin in a kampung that in their classconscious self-imagination they thought to have long left behind.

I thus suggest that the highly ambivalent feelings that dangdut stirs up in middle class and elite Indonesians might also be related to the specific kind of subjectivity constituted by it. In contrast to deeply internalised educated middle and upper class imaginations of modernization and development, characterized by their emphasis on an active subject and a focus on the future and global 'exemplary centers', dangdut is content to be an ephemeral celebration of collective bodily euphoria, just enjoying the present moment without presenting any explicit ideas about an ideal subject of the nation-state. The lyrics, moreover, are preferably backward looking, dwelling melancholically on lost loves, broken promises, past betrayals, often ridiculously exaggerated in their pathos - thus representing a challenge par excellence to any ideology that promises an optimistic 'You Can' that is so cherished and longed for by the middle classes seeking

resistance to identification with sad or male-bashing lyrics, and the pleasure one gains by actively 'not listening to' the textual dimension may well lead to a liberating feeling of autonomy and mental disengagement that is highly valued in Javanese culture (cf. Keeler 1987; see also Siegel 1993). Seen this way, it is the rhythmic-corporeal dimension that becomes some kind of 'first' language, the one that has to be suppressed and disciplined when entering the 'official' realm of the adult socio-symbolic order. In not identifying with the lyrics, the rational-textual dimension is transcended and opened up to other dimensions of being, that is, the pleasurable corporeal 'pre-social' and 'pre-linguistic' ways of being beyond restricting and demanding adult responsibilities. In that way, in identifying with this dimension below or beyond language and the social order structured by it, one can in fact 'forget' the very problems of daily life that the lyrics are often about. 
social upward mobility and international recognition. The passive surrender to dangdut's rhythmic corporeal communion and to the voice of a female, powerless in the lyrical narratives yet powerful in her command of the stage and audience, articulated in a musical idiom that is perceived as some kind of embarrassingly failed kampungan modernity, is, of course, anathema to both developmentalism's emphasis on progress and to any fetishisation of a self-conscious, consumerist global 'Modernity' lifestyle.

Dangdut's subject cannot speak back to the West or offer an alternative identity, just like its articulation of female suffering and male double standards provides no grassroots feminist discourse or supporting women's empowerment. Dangdut's corporeal bliss defies all ideological stances because one is always able to take it ironically, poke fun at it, or euphorically dance it away: dangdut can encompass it all without losing its inclusive soul. At the same time, dangdut's deeply pleasurable ambiguous subjectivity eludes the rigid identifications that are required by ideological identity positions.

In contrast to the active re-working of the symbolic in poetic practice referred to by Kristeva, the irruption of the semiotic element celebrated in dangdut performances does not change and rework the symbolic order, but rather exposes the semiotic basis of language and the symbolic. Change is induced more through 'boundary transgressions', like presenting Inul's dancing kampungan style dangdut in the national media, that lead to public contestations and negotiations about what should be allowed to be seen in which media or social domain. However, the fierce debate about Inul's drilling dance, and what it means to Indonesian legitimate self-representation, was tellingly led mainly by those who are usually not part of the audience at dangdut concerts. Rather, conservative ulama and strongly devout Muslims set the tenor of the debate in terms of Islamic normative stipulations on the one side, with urban activists who identified with global liberalist and human rights discourses taking the opposing side. Dangdut's immediate subjects, the male fans, were left once again without a distinct voice of their own as the ideological framing of the national debate was mainly beyond the reach of their subjectivity. They are still the ones spoken for, either by religious authorities, human rights activists, or the female singer who in many songs laments their multiple failures.

It might be interesting in this regard to compare dangdut with another ideologically mediated cultural idiom that exerts a strong attraction among the middle classes, that is, Islamic resurgence. Like dangdut, Islam 
offers the experience of a shared communitas that is united across social status and class, and like dangdut, Islam offers a discourse to articulate, among others, feelings of grief, sorrow, guilt, as it allows the acknowledgement and negotiation of human imperfection and suffering. Like dang$d u t$, it induces processes of surrender, but in this case to an all-powerful patriarchal God - representing, in Kristeva's terms, the Law of the symbolic order. As this concerns the level of the symbolic, it points toward psychic processes that emphasize rationalization and the emergence of a new kind of idealized subjectivity: the self-conscious pious Islamic subject, who identifies with the one voice of the Law, striving to purify itself of all un-Islamic 'noise'. The Islamic discourses of newly pious believers thus speak of guilt and sin, rather than in categories of shame about being not yet dewasa ('mature'). And, in contrast to dangdut, one is not supposed to take it ironically.

Thus, in contrast to dangdut's subject, Islam can speak with and commands a powerful voice. Seen from this perspective, the new Islamic subjectivity may be attractive to the middle classes because ideologically it offers an identity position that is related to and compatible with other global identities. Like them, Islam urges its subjects to take a clear stance, preferring in its current hegemonic literalist discourses rather rigid 'either - or' identities over ones that are characterized by higher levels of tolerance of ambiguity. These rather closed notions of subjectivity seem to provide an identity ideal that promises to be sufficiently dewasa, so that one need not be ashamed of it, like one would be of dangdut seen through the eyes of the Other/West.

The biggest dangdut hit in 2011 was Alamat palsu (False address) by Ayu Ting Ting. The man left the girl with nothing but an address that turns out to be false, nobody knows the man, she has been cheated and tricked and asks in the refrain, where do I have to look for him? Simple and cliché as this lyrical narrative is, inviting us to straightforwardly enjoy it in a playfully parodied way, at a deeper level it also implies that in life one might also get false addresses, hinting at the ever lurking dangers of losing one's orientation, as the promises of ideologies and ideologised religions may indeed turn out to be nothing more than false addresses.

\section{References}

Anderson, B.R.O'G. Language and power: Exploring political culture in Indonesia. Ithaca, NY: Cornell University Press, 1990.

Bader, S. 'Dancing bodies on stage: Negotiating nyawer encounters at dangdut and tarling dangdut performances in West Java', Indonesia and the Malay World 39:333-55, 2011. 
Bauer, T. Die Kultur der Ambiguität. Eine andere Geschichte des Islams. Berlin: Verlag der Weltreligionen im Insel Verlag, 2011.

Baumann, Z. Modernity and ambivalence. Cambridge: Blackwell Publishers,1993.

Brenner, S.A. The domestication of desire. Women, wealth, and modernity in Java. Princeton, NJ: Princeton University Press, 1998.

Browne, S. The gender implications of dangdut kampungan: Indonesian 'low class' popular music. Clayton: Monash University Centre of Southeast Asian Studies [Monash University Insititute for Asian Studies Working Paper 109], 2000.

David, B. 'Intimate neighbours. Bollywood, dangdut music, and globalising modernities in Indonesia', in: Sangita Gopal and Sujata Moorti (eds), Global Bollywood, Travels of Hindi song-and-dance sequences, pp. 179-99. Minneapolis: University of Minnesota Press, 2008.

Dolar, M. 'If music be the food of love', in: Slavoj Žižek and Mladen Dolar, Opera's second death (eds), pp. 1-102. London/New York: Routledge, 2002.

Frederick, W. 'Rhoma Irama and the dangdut style: Aspects of contemporary Indonesian popular music', Indonesia 34:103-30, 1982.

Heryanto, A. 'Pop culture and competing identities', in: Ariel Heryanto (ed.), Popular culture in Indonesia. Fluid identities in post-authoritarian politics, pp. 1-36. London/ New York: Routledge, 2008.

Keane, W. 'Public speaking: On Indonesian as the language of the nation', Public Culture 15-3:503-30, 2003.

Keeler, W. Javanese shadow plays, Javanese selves. Princeton: University Press Princeton, 1987.

Kristeva, J. Revolution in poetic language. New York: Columbia University Press, 1984.

Langer, S.K. Philosophy in a new key. Cambridge: Harvard University Press, 1957.

Malik, C. 'Saya ingin dangdut go international', Republika. December 24th, 2000.

Matheson-Hooker, V. 200o. 'New Order language in context', in: Virginia Matheson-Hooker (ed.), Culture and society in New Order Indonesia, pp. 272-93. Kuala Lumpur: Oxford University Press, 1995 .

Peletz, M. Reason and passion. Representations of gender in a Malay society. Berkeley: University of California Press, 1996.

Pioquinto, C. 'Dangdut at Sekaten. Female representations in live performance', RIMA 29-1/2:59-89, 1995.

Sarinah. 'Dari redaksi', Sarinah. June 15, 1992. p.3, 1992.

Schade-Poulsen, M. 'The power of love: Raï music and youth in Algeria', in: Vered AmitTalai and Helena Wulff (eds), Youth cultures. A cross-cultural perspective, pp. 81-113. London/New York: Routledge, 1995.

Sears, L.J. Shadows of empire. Colonial discourse and Javanese tales. Durham/London: Duke University Press, 1996.

Sen, K. 'Repression and resistance. Interpretations of the feminine in New Order cinema', in: Virginia Matheson-Hooker, Culture and society in New Order Indonesia, pp. 116-33. Kuala Lumpur: Oxford University Press, 1993.

- Indonesian cinema. Framing the New Order. London: Zed Books, 1994.

Shiraishi, S. Young heroes. The Indonesian family in politics. Ithaca: Cornell University Southeast Asia Program, 1997.

Siegel, J.T. Solo in the New Order. Language and hierarchy in an Indonesian city. Princeton: Princeton University Press. [First edition 1986.], 1993.

Simatupang, L. "The development of dangdut music and its meanings: A study of popular music in Indonesia'. MA thesis, Departement of Anthropology and Sociology, Monash University, Clayton, 1996.

Spiller, H. Erotic triangles. Sundanese dance and masculinity in West Java. Chicago/London: University of Chicago Press, 2010.

Stokes, M. The arabesk debate. Music and musicians in modern Turkey. Oxford: Clarendon Press, 1992. 
Sunindyo, S. 'Gender discourse on television', in: Virginia Matheson-Hooker (ed.), Culture and society in New Order Indonesia, pp. 134-48. Kuala Lumpur: Oxford University Press, 1993 .

Susanto, Budi. 'Dangdut Sekatenan. Penguasa, “Agama”, dan Musik Rakyat di Yogyakarta', in: Moedjanto, G., B. Rahmanto, and J. Sudarminta (eds), Tantangan kemanusiaan universal: antologi filsafat, budaya, sejarah-politik \& sastra : kenangan 70 tahun Dick Hartoko, pp. 195-224. Yogyakarta: Penerbit Kanisius, 1992.

Sutton, R.A. 'Who is the pesindhèn? Notes on the female singing tradition in Java', Indonesia 37:119-33, 1984.

Todorov, T. The conquest of America: The question of the Other. New York: Harper and Row, 1984.

Tony, M. 'Bius sosial di balik goyang dangdut', Basis 3-4 (May-June 1996):42-51, 1996.

Wallach, J. Modern noise, fluid genres. Popular music in Indonesia, 1997-2001. Madison, WI: University of Wisconsin Press. [New Perspectives in Southeast Asian Studies 3], 2008.

Weintraub, A.N. "Dance drills, faith spills": Islam, body politics, and popular music in post-Suharto Indonesia', Popular Music 27-3:367-92, 2008.

- Dangdut stories. A social and musical history of Indonesia's most popular music. Oxford/New York: Oxford University Press, 2010.

Yampolsky, P. 'Hati yang luka: An Indonesian hit', Indonesia 47:1-17, 1989.

Yurnaldi and Rakaryan S. 'Musik dangdut mencapai puncaknya', Kompas, 13 Juli 1997. 